\title{
February 28 Highlight and Commentary
}

\section{Left insular damage predicts cardiac outcome after stroke}

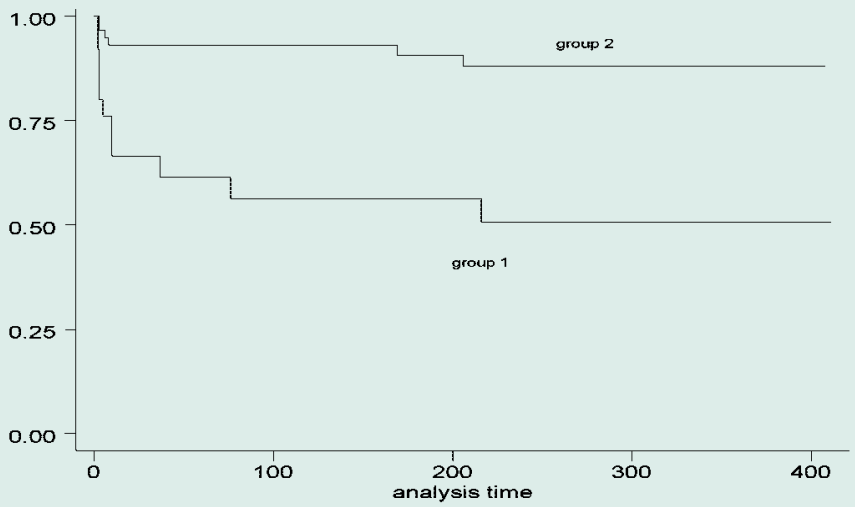

Survival curve comparing survival of patients with and without left insular involvement who did not have underlying symptomatic coronary heart disease.
Right and left insulae maintain differential specialization of cardiovascular regulation. Laowattana et al. found that cardiac outcome was worse than in patients with non-insular stroke/TIA during the year following left insular stroke. This persisted on multivariate analysis and in patients without symptomatic coronary artery disease. Right insular involvement did not affect cardiac outcomes.

see page 477

\section{"Voodoo" death returns: In search of the cardunculus}

\author{
Commentary by Martin A. Samuels, MD, FAAN, MACP
}

During everyday life the heart and the other viscera are autoregulated, but in some extraordinary circumstances, the nervous system may intervene, incidentally damaging the internal organs. The heart is only one example of this phenomenon, but it is particularly salient in that its dysfunction may lead to rapid demise and because its abnormal function may be quickly recognized by EKG.

For centuries people have known that acute life-threatening stressors with no chance of escape or control could lead to sudden death. In 1942, Walter B. Cannon published his landmark account of "Voodoo" death, recounting experiences, mostly from the anthropology literature, of death from fright. ${ }^{1}$ Early EKG studies documented that catastrophic neuropsychiatric conditions produced dramatic alterations in the EKG, particularly its repolarization phase, when an aberrantly conducted beat could result in a life-threatening cardiac arrhythmia. Initially believed to be artifact, "cerebral T waves" clearly represent the tip of an iceberg, above true cardiac damage, mediated by catecholamines released by autonomic terminals in the subendocardium. These catecholamines activate receptor operated calcium channels ultimately leading to free radical mediated myocardial cell death and leak of cardiac enzymes. In extreme cases, frank cardiac failure may ensue with loss of wall motion and dramatic reductions in the ejection frac- tion ("cardiac stunning"). Because of the characteristic appearance of the dyskinetic cardiac apex and relatively normal base, this has been called Takotsubo (octopus tube) cardiomyopathy because the appearance resembles a Japanese octopus trapping pot.

The microscopic cardiac lesion, contraction band necrosis, is distinct from ischemic damage (coagulation necrosis) and is seen in four circumstances that are linked by a unifying mechanism: 1) systemic catecholamine excess (e.g., pheochromocytoma); 2) stress with endogenous catecholamine and steroid release; 3 ) stimulation of the sympathetic nervous system (e.g., epileptic seizures); and 4) reperfusion of the heart after periods of ischemia as in recanalization of coronary arteries by thrombolysis (therapeutic or spontaneous), angioplasty, or coronary bypass surgery. ${ }^{2}$

The concept that unifies seemingly disparate etiologies is neurovisceral (or psychosomatic) disease. If psychological stress can lead to cardiac arrhythmia and myocardial necrosis, there must be a representation of the heart in the brain. The search for the "cardunculus" has led to the insula, a part of the primitive limbic brain. Via the amygdala (the cardiac "basal ganglion"), the outflow leads to the hypothalamus and from there via the sympathetic and parasympathetic nervous system to the heart. The likelihood of the heart's autoregulatory system being overridden must depend on the magnitude of the autonomic storm and several balances (sympathetic vs parasympathetic; right vs left; acute vs chronic). Furthermore, stimulation (e.g., seizures) may have the opposite effect to ablation (e.g., infarction). Because of this complexity, it is often difficult to know the effect of a particular lesion in the brain. Laowattana et al. found poorer cardiac outcomes with left insular strokes, but the precise mode of death was variable. Neurocardiac damage takes many forms: excess parasympathetic activity with severe bradycardia and heart block, excess sympathetic activity with tachycardia, imbalance in autonomic output to the heart with alterations in repolarization patterns, U waves and Q waves.

Every patient with an innervated heart (excluding those with cardiac transplants or severe autonomic neuropathy) are at risk for the intervention of the nervous system into the usual affairs of the heart. The gut, kidney, and other organs are also at risk. Neuropsychiatric events have profound effects on the viscera. We are only just beginning to learn how to prevent or treat the consequences.

\section{References}

1. Cannon WB. "Voodoo" death. Am Anthropol 1942;4:1-10.

2. Samuels MA. "Voodoo" death revisited: the modern lessons of neurocardiology. Neurologist 1997;3:293-304.

see page 477 


\title{
Neurology
}

\author{
February 28 Highlight and Commentary \\ Neurology 2006;66;463 \\ DOI 10.1212/01.wnl.0000203916.49675.77
}

This information is current as of February 27, 2006

\section{Updated Information \&} Services

References

Citations

Permissions \& Licensing

Reprints including high resolution figures, can be found at: http://n.neurology.org/content/66/4/463.full

This article cites 1 articles, 0 of which you can access for free at: http://n.neurology.org/content/66/4/463.full\#ref-list-1

This article has been cited by 1 HighWire-hosted articles: http://n.neurology.org/content/66/4/463.full\#\#otherarticles

Information about reproducing this article in parts (figures,tables) or in its entirety can be found online at:

http://www.neurology.org/about/about_the_journal\#permissions

Information about ordering reprints can be found online:

http://n.neurology.org/subscribers/advertise

Neurology ${ }^{\circledR}$ is the official journal of the American Academy of Neurology. Published continuously since 1951, it is now a weekly with 48 issues per year. Copyright . All rights reserved. Print ISSN: 0028-3878. Online ISSN: 1526-632X.

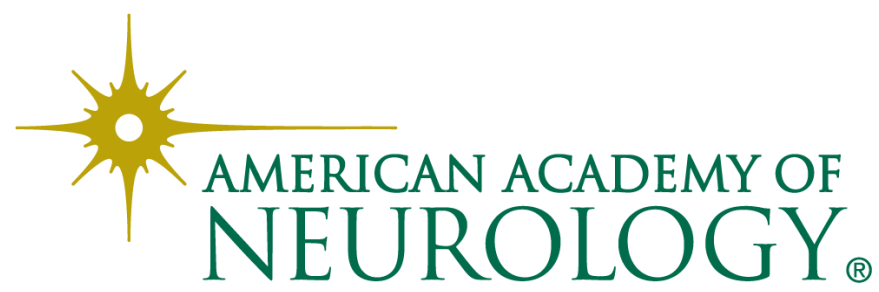

